\title{
ISOLASI BAKTERI FOTOSINTETIK DARI DASAR TAMBAK PADA KONDISI UDARA YANG MENGANDUNG ASAP KENDARAAN BERMOTOR
}

\section{ISOLATION OF PHOTOSYNTHETIC BACTERIA FROM PONDS SEDIMENT AT AIR CONDITION CONTAINS VEHICLE SMOKES}

\author{
Wawan Abdullah Setiawan ${ }^{1}$ \\ 1 Jurusan Biologi FMIPA Universitas Lampung \\ Jurusan Biologi FMIPA Universitas Lampung \\ Jl. Soemantri Brojonegoro No.1, Bandar Lampung, Lampung, Indonesia, 35145
}

\begin{abstract}
Abstrak
Semakin meningkatnya volume kendaraan saat ini berdampak pada meningkatnya polusi asap kendaraan. Asap kendaraan bermotor juga diketahui mengandung $\mathrm{CO}_{2}$ yang mampu meningkatkan pemanasan global. Diketahui bahwa terdapat bakteri fotosintetik yang mampu memfiksasi $\mathrm{CO}_{2}$. Bakteri ini dapat ditemukan di danau, sawah, maupun dasar tambak. Penelitian ini bertujuan untuk mengisolasi bakteri fotosintetik dari berasal dari dasar tambak setelah diberi penambahan asap kendaraan bermotor pada medium kulturnya. Ditemukan terdapat 5 isolat bakteri yang tumbuh; 3 bakteri bersifat gram negatif, 2 berbentuk batang dan 1 berbentuk bulat. 2 bakteri bersifat gram positif dengan bentuk batang.
\end{abstract}

Kata kunci: asap kendaraan, $\mathrm{CO}_{2}$, bakteri fotosintetik, dasar tambak.

\begin{abstract}
Increasingly volume of vehicles currently impacting on the increasing smoke pollution. Vehicle emission also known contain $\mathrm{CO} 2$ that capable to increase the global warming. There is photosynthetic bacteria who capable to fixation of $\mathrm{CO} 2$. This bacterium can be found in lake, rice field, or bottom of pond. The aim of this research for isolate the photosynthetic bacteria from the bottom of pond after were given the addition vehicle smoke on the culturing medium. There are 5 isolates of the bacteria which grown on medium; 3 bacteria identified as gram-negative, 2 shaped rod and 1 shaped rounded. 2 bacteria known as gram-positive with shaped rods.
\end{abstract}

Keywords: vehicle emission, $\mathrm{CO}_{2}$, photosynthetic bacteria, ponds sediment.

\section{PENDAHULUAN}

Pemanasan global (global warming) yang terjadi dewasa ini disebabkan oleh meningkatnya konsentrasi $\mathrm{CO}_{2}$ di atmosfir. Adanya peningkatan $\mathrm{CO}_{2}$ sebagai gas rumah kaca ini dapat menyebabkan ketidakseimbangan ekosistem. Salah satu sumber emisi $\mathrm{CO}_{2}$ yang cukup besar adalah gas buang dari kendaraan bermotor. Fiksasi $\mathrm{CO}_{2}$ merupakan salah satu cara untuk mengatasi permasalahan global warming akibat emisi $\mathrm{CO}_{2}$. Fiksasi $\mathrm{CO}_{2}$ dapat dilakukan dengan beberapa cara antara lain dengan pembuatan pupuk (urea), penggunaaan tumbuhan tingkat tinggi, dan penggunaan mikroalga. Fiksasi $\mathrm{CO}_{2}$ dalam bentuk pupuk (urea) tidak bersifat permanen karena tanaman hanya memanfaatkan unsur nitrogen dari urea, sedangkan unsur karbon lebih banyak diserap dalam bentuk gas $\mathrm{CO}_{2}$ di atmosfir. Gas $\mathrm{CO}_{2}$ terfiksasi dalam jumlah besar dengan penggunaan tumbuhan tingkat tinggi. Namun penggunaan tumbuhan ting- kat tinggi memiliki kelemahan yaitu waktu generasinya panjang.

Bakteri fotosintetik merupakan mikroba yang mampu melakukan fotosintesis anoksigenik, dimana bakteri ini mampu menggunakan sumber karbon dari gas karbon dioksida untuk memperoleh nutrisinya dan tidak menghasilkan oksigen sebagai akseptor elektron terakhir dari proses fotosintesis. Sebagian besar spesies dapat tumbuh secara fotoautotrof menggunakan $\mathrm{CO}_{2}+\mathrm{H}_{2}$ atau $\mathrm{CO}_{2}+\mathrm{H}_{2} \mathrm{~S}$ konsentrasi rendah. Bakteri ini tumbuh pada lingkungan anaerob seperti di dasar tambak, danau, lumpur, dan tanah sawah. Di perairan tambak, bakteri fotosintetik bersama mikroba lainnya diaplikasikan untuk memperbaiki kualitas air untuk meningkatkan proses produksi.

Sampai saat ini telah diketahui bahwa pengayaan udara bebas dengan $\mathrm{CO}_{2}$ mampu meningkatkan keragaman bakteri fotosintetik hasil isolasi dari tanah sawah tergenang. Selain 
sawah, bakteri fotosintetik juga ditemukan di dasar tambak, danau, dan lumpur (Madigan dan Martinko. 2012). Sebagaimana diketahui bahwa pertumbuhan makhluk hidup termasuk bakteri fotosintetik bergantung pada faktor internal yang meliputi kode genetik dan faktor eksternal berupa faktor lingkungan. Faktor lingkungan ini termasuk kondisi media kultur dan udara. Grau (1991) telah menerangkan medium kultur khusus untuk bakteri fotosintetik

Feng dkk. (2009) menemukan bahwa pengayaan udara bebas dengan $\mathrm{CO}_{2}$ mampu meningkatkan keragaman bakteri fotosintetik hasil isolasi dari tanah sawah tergenang. Bakteri dengan kemampuan tumbuh logaritmiknya yang cepat diharapkan mampu membantu mengurangi $\mathrm{CO}_{2}$ di atmosfir. Emisi gas kendaraan bermotor mengandung $\mathrm{CO}_{2}$ diduga dapat difiksasi oleh bakteri fotosintetik bakteri fotosintetik dari dasar tambak berpotensi mengurangi pemanasan global. Untuk itu pada penelitian ini dilakukan pengkajian tentang kemampuan pertumbuhan bakteri fotosintetik dari dasar tambak pada kondisi udara yang mengandung asap kendaraan bermotor.

\section{BAHAN dan METODE}

Penelitian ini dilakukan di laboratorium mikrobiologi FMIPA Universitas Lampung mulai buIan Mei sampai September 2010. Sampel lumpur dasar tambak diperoleh dari tambak masyarakat di Kecamatan Labuhan Maringgai, Lampung Timur. Bakteri fotosintetik diisolasi dengan metode Winogradsky (Grau. 1991). Salinitas perairan tambak diukur dengan refraktometer untuk menyamakan salinitas air yang digunakan dalam pembuatan media perkayaan bakteri fotosintetik.

Mula-mula disiapkan bahan-bahan untuk kolom Winogradsky. Dibuat campuran kental selulosalumpur menggunakan bubuk selulosa. Bubuk selulosa ditambahkan 1-2 gram dalam sedikit air lalu dimasukkan ke dalam lumpur. Selulosalumpur kental tersebut dimasukkan ke dalam tabung sampai $1 / 3$ volume tabung. Ke dalam 200 gram lumpur yang lain, ditambahkan 1,64 gram kalsium sulfat dan masing-masing 1,3 gram kalsium karbonat dan dipotasium posfat. Ke dalam campuran ke-3 ditambahkan air lumpur dan dilarutkan dengan batang pengaduk. Lumpur ini ditambahkan ke dalam kolom pada bagian atas selulosa kental yang sebelumnya telah dibuat. Kedua adukan lumpur diaduk dengan batang pengaduk. Saat diaduk campuran dimasukkan ke dalam kolom. Ketika mengaduk ditambahkan air dari genangan lumpur. Campuran selulosa/lumpur/air dibuat kira-kira 2/3 volume kolom. Kemudian ditambahkan lagi air lumpur sampai $90 \%$ volume kolom. Kolom kemudian ditutup dengan alumunium foil untuk menghindari penguapan dan diinkubasikan pada suhu ruang selama 2 minggu. Setelah 2 minggu alumunium foil dilepas. Tanpa menutup kolom kembali dipasang lampu beberapa $\mathrm{cm}$ dari kolom. Kemudian diinkubasikan pada suhu ruang selama beberapa minggu sampai terbentuk lapisan-lapisan berwarna pada kolom.

Setelah terbentuk lapisan-lapisan berwarna, dilakukan isolasi bakteri fotosintetik (Grau,1991). Dari kolom Winogradsky, diambil lapisan air yang berwarna coklat atau kemerahan yang berada di atas permukaan lumpur. Isolat sebanyak $1 \mathrm{ml}$ dipindahkan ke medium perkayaan bakteri fotosintetik yaitu medium Van Niel's Yeast cair (Atlas. 2006). Isolat dikulturkan di media dalam tabung tertutup dengan volume media $2 / 3$ volume tabung, sisanya dibiarkan berisi udara. Tabung kemudian ditutup lalu ditaruh di bawah cahaya lampu 75 watt dengan jarak 15-20 cm dari lampu. Diinkubasi pada suhu $25^{\circ} \mathrm{C}$ selama 7 hari.

Isolat yang didapat kemudian dihitung keragamannya dengan cara menumbuhkannya secara goresan pada cawan petri berisi media perkayaan bakteri fotosintetik padat. Isolat kemudian diinkubasi dalam tabung anaerob di bawah cahaya lampu 75 watt dengan jarak 15$20 \mathrm{~cm}$. Mikroba yang tumbuh kemudian dimurnikan pada cawan petri berisi medium Van Niel's Yeast padat. Isolat kemudian diinkubasi dalam tabung anaerob di bawah cahaya lampu 75 watt dengan jarak $15-20 \mathrm{~cm}$. Penentuan keragaman didasarkan pada morfologinya yang meliputi bentuk koloni, warna koloni, tepian koloni, elevasi koloni, dan bentuk selnya.

Setelah isolat bakteri fotosintetik dari dasar tambak didapatkan, dilakukan uji kemampuan tumbuh isolat pada kondisi udara yang mengandung asap kendaraan bermotor. Mulamula disiapkan tabung-tabung percobaan berisi medium Van Niel's Yeast cair. Tiap tabung ditambahkan sebanyak $1 \mathrm{ml}$ diisi isolat bakteri fotosintetik. Ke dalam tiap tabung dimasukkan asap kendaraan bermotor. Dalam penelitian ini dipilih asap hasil emisi sepeda motor 4-tak berbahan bakar bensin. Asap tersebut ditambahkan ke dalam tabung sebanyak 0,1 kali volume tabung. Sebagai kontrol, satu tabung tidak ditambahkan asap. Tabung kemudian ditutup lalu ditaruh di bawah cahaya lampu 75 watt dengan jarak 15-20 cm dari lampu. Setelah itu diinkubasi pada suhu ruang selama 7 hari. Pertumbuhan bakteri diamati dengan cara menghitung jumlah total bakteri secara langsung dengan mikroskop. 


\section{HASIL dan PEMBAHASAN}

Berdasarkan kolom Winogradsky, diketahui bahwa lapisan-lapisan berwarna mulai tampak jelas pada hari ke-12 (gambar 1). Lapisan air berwarna coklat kemerahan di atas permukaan lumpur diduga sebagai bakteri non sulfur fotosintetik ungu. Grau et al (1991) menerangkan bahwa lapisan air di atas permukaan lumpur kolom Winogradsky merupakan lapisan yang dihuni oleh bakteri fotosintetik. Madigan dan Martinko (2006) menyebutkan bahwa kombinasi pigmen bakterioklorofil dan pigmen karotenoid yang dimiliki oleh anggota bakteri fotosintetik menghasilkan warna kultur beragam, mulai coklat, ungu, ungu kemerahan, dan hijau. Grau et al (1991) menjelaskan bahwa lapisan-lapisan pada kolom Winogradsky akan muncul setelah minggu ke-2 sampai minggu ke-3 inkubasi, sesuai dengan waktu kemunculan lapisan pada penelitian ini.

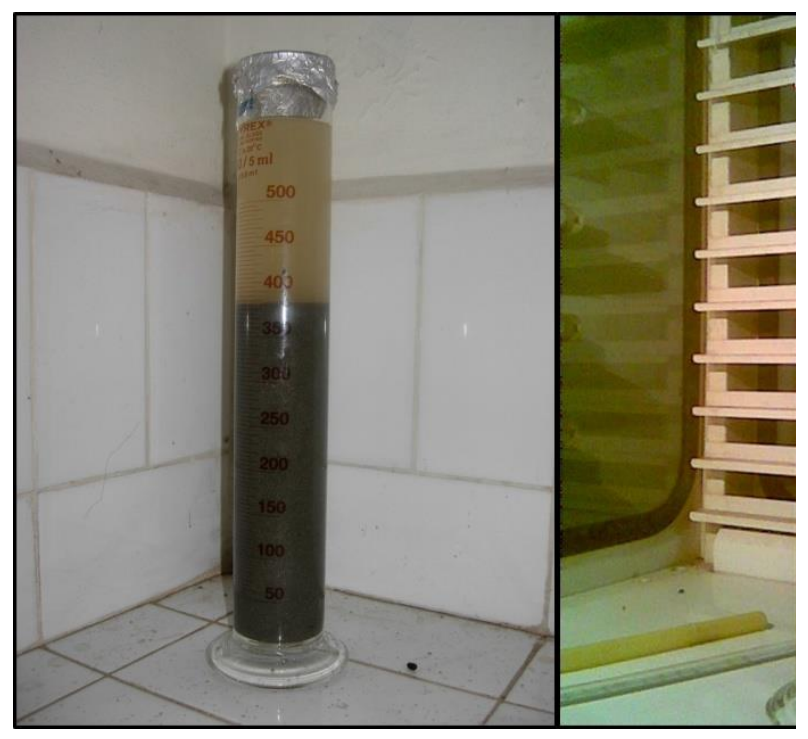

Gambar 1. Kolom Winogradsky hari ke-1 (kiri) dan hari ke-12 (kanan). a. Lapisan warna coklat kemerahan; b. Lapisan warna coklat; c. Lapisan warna hijau.

Lapisan di atas permukaan lumpur (gambar 1a) diisolasi dengan metode Grau. (1991). Lapisan ini dipilih karena terdapat bakteri fotosintetik anoksigenik (Grau et al. 1991; Hunter et al. 2008) yang mampu memfiksasi $\mathrm{CO}_{2}$ (Hunter et al. 2008). Isolat-isolat yang didapatkan kemudian dikulturkan pada media perkayaan (Grau.1991) yang ditambahkan asap kendaraan. Hasil isolasi menunjukkan bahwa terdapat 5 isolat bakteri (gambar 2). Isolat I (gambar 2a) berbentuk batang, bersifat gram negatif, dengan penataan diplobasil. Isolat II (gambar 2b) berbentuk batang, bersifat gram negatif, dengan penataan diplobasil. Isolat II (gambar 2b) berbentuk batang, bersifat gram negatif, dengan penataan mikrobasil. Isolat III (gambar 2c) berbentuk bulat, bersifat gram negatif, dengan penataan mikrobasil. Isolat IV (gambar 2d) berbentuk batang, bersifat gram positif, dengan penataan streptobasil. Isolat $\mathrm{V}$ (gambar 2e) berbentuk batang, bersifat gram positif, berspora dengan letak sentral maupun terminal, dan penataan mikrobasil. Sesuai dengan pernyataan Hunter et al. (2009), bakteri fotosintetik kebanyakan bersifat gram negatif, walaupun ada beberapa gram positif. Ini menunjukkan bahwa isolat yang didapatkan sudah sesuai dengan referensi yang ada. Untuk mengetahui spesies spesifik dari masingmasing isolat yang didapat, diperlukan uji lanjutan yaitu uji biokimia dan identifikasi sekuen DNA.

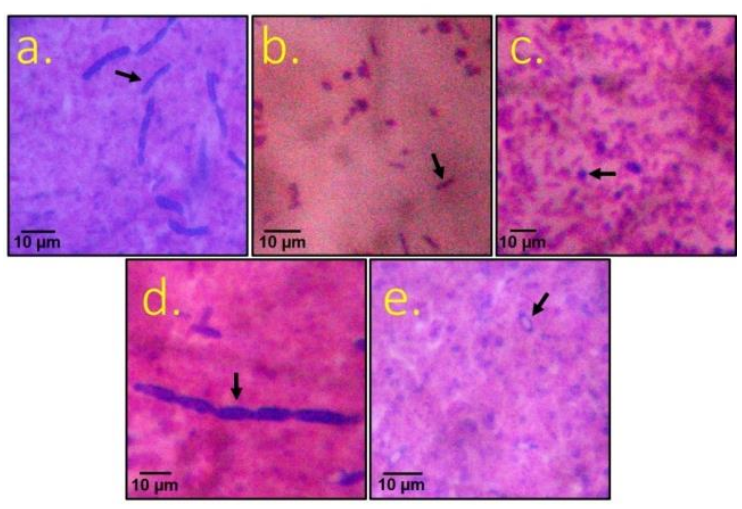

\section{KESIMPULAN}

Terdapat 5 isolat bakteri dari dasar tambak yang tumbuh pada kondisi udara yang mengandung asap kendaraan bermotor. 3 bakteri bersifat gram negatif, 2 berbentuk batang dan 1 berbentuk bulat. 2 bakteri bersifat gram positif dengan bentuk batang.

\section{UCAPAN TERIMAKASIH}

Terimakasih penulis ucapkan kepada Direktorat Jendral Pendidikan Tinggi atas bantuan dana penelitian melalui DIPA Dosen Yunior Universitas Lampung tahun 2010.

\section{DAFTAR PUSTAKA}

Atlas RM. 2005. Handbook of Media for Environmental Microbiology. Ed ke-2. CRC Press. Boca Raton. ISBN 10: 08493-3560-4. Atlas RM. 2005. Handbook of Media for Environmental Microbiology. Ed ke-2. CRC Press. Boca Raton. ISBN 10: 0-8493-3560-4.

Grau RR, Limansky AS, Ricci JCD, Mendoza DD. 1991. The Windogradsky Column: 
A Simple and Inexpensive Approach to Teach Environmental Biochemistry. Biochemical Education. 19(3):143-147.

Hunter CN, Daldal F, Thurnauer MC, Beatty JT. 2009. Advances in Photosynthesis and Respiration Volume 28: The Purple
Phototrophic Bacteria. Springer. Netherland. ISBN 978-1-4020-8814-8.

Madigan MT, Martinko JM, Stahl DA, Clark DP.

2012. Brock Biology of Microorganisms.

Ed ke-13. San Francisco: Pearson

Education. ISBN:978-0321649638. 